一つの村，あるい惟落の児童などの発育成長をなが わて，保健衛生に関する指導玉たは教育に応用しょうと するとき，計測資料が質的及び量的に不備なことから， しばしば壁にぶつかる。この困難を打開するために著者 は，実際の計測資料の数值だけにたよることなく，それ と同時に，身長，体重，坐高等の発育経過汇関寸る理論 を十分顧慮することによりり，その地区に対する身長， 体重その他仙いて成長曲線（発育曲線）の一応の基 準的な経過を設定することを試みた。

この方式は，理論上，あらかじめ承認する成長曲線の 経過济適合するように，アービトラリーに実湘を修正す るものであり，また見方によって纯理論的な成長曲線の 性格を具えた一つの曲線を画く際，その走向，彎曲など 関する数値をきめるにあたって，実測結果を重要視し たものだともいらことができる。

この操作にあたって, 顧慮した要点に，(1)各項目に関 する成長曲線の走り方 $\mathrm{x}=\mathrm{f}(\mathrm{t})$ 加全国平均值でどらな っているかといらこと，(2)その傾斜あるいは年加增加率 の年令変化 $\mathrm{dx} / \mathrm{dt}=\mathrm{f}^{\prime}(\mathrm{t}), \quad(3)$ これらの性䓄筫に関する地 域的差異として，理論上知られている傾问，(4)得らるべ き基準成長曲線は，それ自身に拈いても，全国值の曲線 にくらべての差異和いても，走南が急激に灀向するこ となく，曲線の走向に㪊められる量的性質の変化は徐々 に進行するものであること，等である。

\section{4. 身体発育値の均一度についての綜合的考察}

安倍弘毅，矢野邦夫，諸富嘉男

(久大衛生環境衛生)

従来，身体発育の定成にいたる経過を推察するために $\mathrm{G}^{1 / 3}$ とLとの関係を見ることが，合理的であると涩め たのである。今回さらに身体発青状態の地域差，あるい は諸条件による差暴を检討するため，身体発育值の均一 度を綜合的に把握する方法を考毜た。

即々各人についての身長を $\mathrm{x}_{i}$ ，体重の立方根を $\mathrm{y}_{i}$ ， $\mathrm{x}_{i}, \mathrm{y}_{i}$ の平均値をそれぞれ $\overline{\mathrm{x}}, \overline{\mathrm{y}}$ としたとさ，点 $(\overline{\mathrm{x}}, \overline{\mathrm{y}})$ 之各点 $\left(\mathrm{x}_{i} ， \mathrm{y}_{i}\right)$ との距離の平均をもって，即ち

$$
\frac{1}{\mathrm{n}} \sum_{\mathrm{i}=1}^{\mathrm{n}} \sqrt{\left(\mathrm{x}_{i}-\overline{\mathrm{x}}\right)^{2}+\left(\mathrm{y}_{i}-\overline{\mathrm{y}}\right)^{2}}
$$

にて散布の度合を表し，身長・体重等身体発育值を綜合 的に見た場合の均一度を各集団についてしらべた。

\section{5. 陸上自衛官の体位と体カについて}

北 博正, 前田 博, 野見座一生 （医歯大衛生）
野牛 弘，杉浦保男（防衛打壁幕衛生裸） 近藤正文（陸上自衛隊衛生学校）

青少年の体位执よび体打関する研究は必らずしも少 なくないが，30才以上の壮年期に括ける体位拉よび体力 に関する研究はまれである。これは被検者に適当なグル 一プを見い出し得ないことも，その一つの原因かと思わ れる。

私た台は，さいわい，全国の陸上自衛官を対象に，体 位（身長，体重，胸团）と体力検定 ( $100 \mathrm{~m}$ 疾走，ソフ

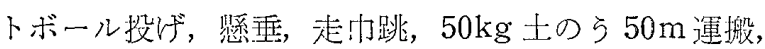
$1500 \mathrm{~m}$ 駆走等）の測定值を得る機会にめぐ李れたので， 18４5才の年令檿にわたって，体位体，力との関係を検 討したので報告する。

\section{6. 生理的年令及び社会的能カからみた老化現象の個} 人差について

过 達彦，児自五郎，小川雅子，森山干代乃 (群大公衛)

伴 真也（群馬中央総合病院）

老令になるにしたがって，歴年令は同じでも，生理的 㙨能や社会的能力の個人差は，かなり著明である。吾々 はいわゆる老化現象がぞのような場合に促進西るいは阻 止されかを見るために，一町村の60才以上の老人約 200 名について，老化現象を生理的な面之社会的能力に分け てしらべた。生理的機能としては，握力，重量テスト， 脑活量, 脊柱の前屈性検查を行ない，李た社会的能力以 日常生活放よび社会生活についての種々の能力を質開調 查より求めて，老化現象との関係を検討した。

\section{7. スポーツの体カに及ぼす影筤について}

北 博正, 前田 博, 山口 裕, 梨本一毁, 野見江一生，五十嵐棌，中山博文，田中重照， 森本 繁(医崡大衛生) 伊藤良夫（東京裥船大） 切瀬锥国，市岡正弘（日本鋼管）

N.K.事業所において，スポーツの体力に及ぼす影響 を調查するため，スポーツを実施している群，スポーツ を行なわ齐群，それぞれ 200 名をえらび，身長，体重， 胸囲，握力，肺機能テスト，運動真背に対するエネルギ 一代謝量, 脉搏の変化, 反応速度の测定等を行ない, 両 群，及び年令別，職種別について比棪検討を行なった。

\section{8． 学徒の栄荃状態に関する研究 （第 4 報）} 川烟愛義，八木 保（京大教養） 